\title{
Fulminant acute hepatitis in pediatrics in Latin America and the Caribbean
}

\author{
(iD) José Colleti Junior, \\ Felipe Rezende Caino ${ }^{1,3}$ \\ (iD) Rafael Teixeira ${ }^{3}$ \\ (D) Werther Brunow de Carvalho ${ }^{4}$
}

\begin{abstract}
1. Department of Pediatrics, Santa Catarina Hospital, São Paulo, SP, Brasil 2. Pediatric ICU, Assunção Hospital, São Bernardo do Campo, São Paulo, SP, Brasil 3. Institute of Pediatric Oncology (GRAACC), São Paulo, SP, Brasil 4. Children's Institute, University of São Paulo, São Paulo, SP, Brasil
\end{abstract}

http://dx.doi.org/10.1590/1806-9282.65.6.914

\section{SUMMARY}

OBJECTIVE: The objective of this review was to investigate the epidemiology of Fulminant Acute Hepatitis in Latin America and the Caribbean and identify possible measures aimed at a better understanding and improvement of patient support.

METHODS: We used 3 different researchers to investigate the topic of Fulminant Acute Hepatitis in pediatrics in papers published by Latin American and Caribbean authors in the PubMed and SciELO databases from 2000 to 2016.

RESULTS: We found 2,879 articles in the databases searched. After selecting and excluding articles according to the study protocol, 68 remaining studies were obtained for analysis. A total of 1,265 cases of acute fulminant hepatitis were detected, with a predominance of females (42.9\%), followed by males (39.4\%), with no description of sex in $17.7 \%$ of the cases. The main cause was viral hepatitis, representing $45.1 \%$ of the cases. The hepatitis A virus was responsible for $34.7 \%$ of the total cases and $76.9 \%$ of the infectious causes. Of the total number of patients, $26.9 \%$ were described as idiopathic, and $11.5 \%$ had no cause.

CONCLUSION: The preventable causes of Fulminant Acute Hepatitis include hepatitis viruses - primarily the hepatitis A virus - and poisoning. Active vaccination, basic sanitation, and public awareness can reduce the number of patients and, consequently, the costs of liver transplantation due to these causes.

KEYWORDS: Hepatitis. Viral hepatitis vaccines. Liver transplantation. Review.

\section{INTRODUCTION}

Fulminant Acute Hepatitis (FAH) is a serious and dynamic clinical syndrome characterized by the quick worsening of hepatic function in patients without a history of liver disease. ${ }^{1.2}$ Both the epidemiology and etiology of FAH are little known, especially in pediatrics. It has several causes, the main ones being acetaminophen poisoning, infections (especially viral ones), metabolic diseases, autoimmune diseases, among others.

The interval between the onset of symptoms and hepatic encephalopathy has determined different definitions for $\mathrm{FAH}^{2.3}$ Although these definitions may differ in some clinical aspects, in clinical practice, they are usually not used. Actually, hepatic en- 
cephalopathy (HE) can be subtle in pediatric patients with FAH or may not even manifest until the end stage of the disease, which makes it not essential for the clinical diagnosis.

It is estimated that spontaneous recovery occurs in only $15-20 \%$ of patients with $\mathrm{HE}^{4}$ and that FAH is responsible for $10-15 \%$ of all pediatric liver transplants. ${ }^{5}$ Due to the absence of therapies that effectively restore hepatocyte function or promote its regeneration, the support treatment is one of the few options before liver transplantation. ${ }^{6.7}$ The prognosis is determined based on the complications caused by acute liver failure (ALF), including cerebral edema, sepsis, and multiple organ dysfunction.

Considering the great heterogeneity of causes, the few possibilities of effective treatments after the IHA and the frequent complications from HAF, preventive measures are still the primary means of reducing morbidity and mortality. ${ }^{8}$ In this context, the countries of Latin America and the Caribbean comprise a list of countries with low to medium Human Development Index, and preventive measures about FAH could be implemented to reduce its incidence. ${ }^{9}$

The objective of this review was to investigate the epidemiology of FAH in Latin America and the
Caribbean and identify possible measures aiming at a better understanding and the improvement of the patient support.

\section{METHODS}

For the selection of the articles analyzed in this review, the PubMed and SciELO databases were searched by three different researchers (JCJ, RT, and FC), as shown in Figure 1.

We included studies of the following modalities: prospective or retrospective cohort, papers of systematic and non-systematic review and clinical trials, case reports, and case series containing a description of patients with HAF with a maximum age of 18 years. Only studies available in Portuguese, English, or Spanish were considered.

In the search mechanisms, the following terms were used: acute OR fulminant AND liver OR hepatic AND failure in the PubMed database and acute liver failure/falla hepática aguda in the SciELO database. We used three filters: for languages (English, Portuguese and Spanish), age (pediatrics), and date of the study (from 2000 up to 2016). All references were checked to decrease the possibility of excluding any relevant studies.

TABLE 1 - DISTRIBUTION OF INFECTIOUS FAH PER COUNTRY OF ORIGIN.

\begin{tabular}{l|l|l|l|l|l|l|l}
\hline Infectious causes & Brasil & $\begin{array}{l}\text { Argen- } \\
\text { tina }\end{array}$ & Chile & Cuba & Others & Total & $\%$ \\
\hline Hepatitis A & 99 & 268 & 61 & 0 & 11 & 439 & 76.9 \\
\hline Hepatitis B & 26 & 2 & 2 & 0 & 0 & 30 & 5.3 \\
\hline Hepatitis C & 0 & 0 & 0 & 1 & 0 & 1 & 0.2 \\
\hline Hepatitis D & 5 & 0 & 0 & 0 & 0 & 5 & 0.9 \\
\hline Hepatitis E & 2 & 35 & 0 & 0 & 1 & 38 & 6.7 \\
\hline Hepatitis A+C & 1 & 0 & 0 & 0 & 0 & 1 & 0.2 \\
\hline Hepatitis A+B & 1 & 0 & 0 & 0 & 0 & 1 & 0.2 \\
\hline Hepatitis B + D & 8 & 0 & 0 & 0 & 0 & 8 & 1.4 \\
\hline Chronic Hepatitis B+C & 1 & 0 & 0 & 0 & 0 & 1 & 0.2 \\
\hline Chronic Hepatitis B+D & 6 & 0 & 0 & 0 & 0 & 6 & 1.1 \\
\hline Viral Hepatitis, untyped & 0 & 0 & 7 & 0 & 0 & 7 & 1.2 \\
\hline Yellow Fever & 13 & 0 & 0 & 0 & 0 & 13 & 2.3 \\
\hline Leptospirosis & 1 & 0 & 0 & 0 & 0 & 1 & 0.2 \\
\hline Rubella & 2 & 0 & 0 & 0 & 0 & 2 & 0.4 \\
\hline Parvovirus B19 & 0 & 0 & 2 & 0 & 0 & 2 & 0.4 \\
\hline Dengue & 0 & 0 & 0 & 1 & 0 & 1 & 0.2 \\
\hline Schistosomiasis & 1 & 0 & 0 & 0 & 0 & 1 & 0.2 \\
\hline Herpes & 1 & 0 & 0 & 2 & 0 & 3 & 0.5 \\
\hline CMV & 0 & 0 & 0 & 8 & 0 & 8 & 1.4 \\
\hline EBV & 0 & 1 & 1 & 1 & 0 & 3 & 0.5 \\
\hline TOTAL & 145 & 306 & 73 & 13 & 12 & 571 & 100.0 \\
\hline
\end{tabular}


FIGURE 1 - FLOWCHART OF THE SEARCH ON PUBMED AND SCIELO DATABASES.

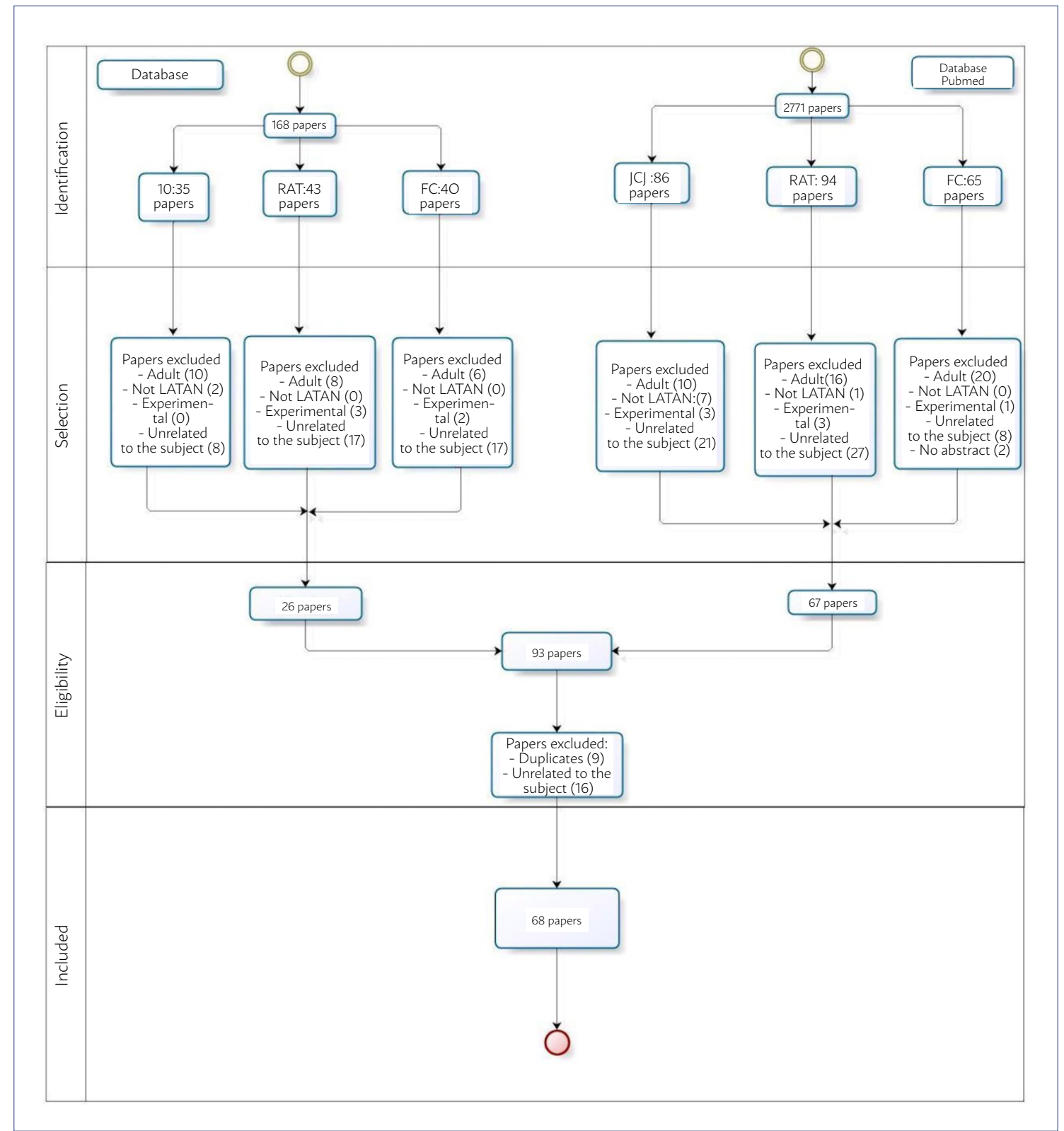

We adopted the following exclusion criteria: duplicate studies, editorials in journals, book chapters, papers retrieved by the search terms but which no relation to the subject of the review, studies in adult patients, experimental studies, and articles not related to the Latin America and Caribbean regions.

The data obtained were entered into tables, and the sum of the columns and the averages were calculated. The chi-square test and the Student's t-test were used for statistical analysis.

\section{RESULTS}

We found 2,879 articles in the databases searched. After the initial selection, we evaluated the titles or abstracts and removed 2,785 papers based on the exclusion criteria; a total of 92 publications were left for evaluation. After further verification, we excluded another 24 articles ( 8 duplicates and 16 not related to the topic of the study). As a result, there were 68 remaining studies for analysis. ${ }^{10-77}$

Of the studies analyzed, 34 were published in international journals and 34 in national journals of their respective countries. In total, we evaluated FAH 1,265 cases, with a predominance in females $(42.9 \%)$, followed by males (39.4\%); in $17.7 \%$ of cases, there was no description of sex.

The virus, especially those of hepatitis, were the main causes for ALF, in $45.1 \%$ of the cases. The hepatitis A virus was responsible for $34.7 \%$ of the total 
number of cases and $76.9 \%$ of infectious causes. Other viruses such as parvovirus, herpes, cytomegalovirus, Epstein-Barr, dengue, and rubella were also described. Of the total of patients, 340 (26.9\%) were described as idiopathic, and 145 (11.5\%) had no cause described. Table 1 shows the distribution of infectious HAF per country of origin.

We found 62 cases (4.9\%) of autoimmune diseases, and poisoning accounted for $3.4 \%$ of cases, the most common being poisoning by fireworks $(27.9 \%)$, followed by the use of isoniazid (16.3\%). Paracetamol was reported in only $0.2 \%$ of all cases of ALF and in $4.6 \%$ of the drug causes.

The countries that had the most published articles on FAH were Brasil (30.4\%), Chile (24.3\%), and Argentina (18.8\%). Reports were also found from the following countries: Peru, Uruguay, Colombia, Costa Rica, Mexico, and Cuba.

Other data found also refers to the number of deaths and transplant patients. There were a total of

TABLE 2 - MAIN ALF STUDIES IN LATIN AMERICA AND THE CARIBBEAN.

\begin{tabular}{|c|c|c|c|c|c|}
\hline $\begin{array}{l}\text { Author/ } \\
\text { Country }\end{array}$ & Objective & Intervention & Controls & Sample & Results \\
\hline $\begin{array}{l}\text { Moreira-Silva } \\
\text { et al. }{ }^{\mathbf{1 0}}, 2002, \\
\text { Brasil }\end{array}$ & $\begin{array}{l}\text { Description of } \\
\text { a series of ALF } \\
\text { cases in children }\end{array}$ & None & $\begin{array}{l}\text { Evaluated biochem- } \\
\text { ical and serological } \\
\text { tests of patients }\end{array}$ & 46 patients & $\begin{array}{l}38 \text { patients with hepatitis A; } 2 \text { cases with hepa- } \\
\text { titis B, and } 6 \text { cases with no diagnosis; mortality } \\
\text { of } 50 \%\end{array}$ \\
\hline $\begin{array}{l}\text { Uribe et al. }{ }^{39} \\
2005 \text {, Chile }\end{array}$ & $\begin{array}{l}\text { Analysis of } \\
\text { epidemiology and } \\
\text { outcomes of LT in } \\
\text { ALF in Chile }\end{array}$ & $\begin{array}{l}\text { LT in patients } \\
\text { from the waiting } \\
\text { list for liver } \\
\text { transplantation } \\
\text { in the country }\end{array}$ & $\begin{array}{l}\text { Use of steroids, } \\
\text { cyclosporine, and } \\
\text { azathioprine, with the } \\
\text { use of mycopheno- } \\
\text { late, and tacrolimus in } \\
\text { some cases. }\end{array}$ & $\begin{array}{l}42 \text { patients, } 27 \\
\text { submitted to } L T\end{array}$ & $\begin{array}{l}27 \text { patients with LT: } 13 \text { females; } 1 \text { male; } 10 \text { with } \\
\text { hepatitis } A ; 3 \text { autoimmune; } 12 \text { cryptogenic; } \\
7 \text { died after LT, with } 3 \text { unsuccessful retrans- } \\
\text { plantations; } 20 \text { patients were discharged } \\
\text { with } 5 \text {-year follow up after the procedure and } \\
\text { survived }\end{array}$ \\
\hline $\begin{array}{l}\text { Cuarterolo et } \\
\text { al. }{ }^{40}, 2005 \\
\text { Argentina }\end{array}$ & $\begin{array}{l}\text { The child evolu- } \\
\text { tion during the } \\
\text { first year after LT }\end{array}$ & $\begin{array}{l}\text { All patients } \\
\text { received cyclo- } \\
\text { sporine }\end{array}$ & $\begin{array}{l}\text { Periodic examinations } \\
\text { during the first year } \\
\text { after LT }\end{array}$ & 143 patients & $\begin{array}{l}\text { Of the } 143 \text { patients, } 14 \text { needed retransplanta- } \\
\text { tions }\end{array}$ \\
\hline $\begin{array}{l}\text { Ciocca et al. }{ }^{33}, \\
\text { 2008, Argen- } \\
\text { tina }\end{array}$ & $\begin{array}{l}\text { Study the etiol- } \\
\text { ogy, outcome, } \\
\text { and prognosis in } \\
\text { children with ALF }\end{array}$ & None & $\begin{array}{l}\text { Patient follow up until } \\
\text { hospital discharge, } \\
\text { death, or LT }\end{array}$ & $\begin{array}{l}215 \text { patients, but } \\
\text { only } 210 \text { with } \\
\text { medical records }\end{array}$ & $\begin{array}{l}128 \text { patients with hepatitis } A, 68 \text { indetermi- } \\
\text { nate, and } 13 \text { of other causes; } 59 \text { survived with } \\
\text { hospital discharge and no LT; } 61 \text { died and } 90 \\
\text { received LT }\end{array}$ \\
\hline $\begin{array}{l}\text { Ferreira et al. }{ }^{31} \\
\text { 2008; Brasil }\end{array}$ & $\begin{array}{l}\text { Retrospective re- } \\
\text { port of the last } 10 \\
\text { years of children } \\
\text { with ALF due to } \\
\text { hepatitis A }\end{array}$ & None & $\begin{array}{l}\text { Evaluated biochem- } \\
\text { ical and serological } \\
\text { tests of all patients }\end{array}$ & 33 patients & $\begin{array}{l}13 \text { patients were positive for hepatitis } A, 11 \text { had } \\
\text { no cause determined, } 1 \text { had a spontaneous } \\
\text { recovery, } 5 \text { died before LT, } 7 \text { underwent LT with } \\
\text { total survival after of } 4 \text { patients ( } 1 \text { with no LT } \\
\text { and } 3 \text { without after LT) }\end{array}$ \\
\hline $\begin{array}{l}\text { Roque et al. }{ }^{61} \\
\text { 2009, Chile }\end{array}$ & $\begin{array}{l}\text { Report the } \\
\text { experience of a LT } \\
\text { center }\end{array}$ & $\mathrm{LT}$ & $\begin{array}{l}\text { Evaluated biochem- } \\
\text { ical and serological } \\
\text { tests of all patients }\end{array}$ & $\begin{array}{l}8 \text { patients } \\
\text { underwent LT } \\
\text { between } 1997 \\
\text { and } 2008\end{array}$ & $\begin{array}{l}5 \text { patients received LT from a dead donor; } 5 \\
\text { female patients; } 3 \text { had kidney failure, with } 2 \\
\text { deaths among the } 8 \text { patients }\end{array}$ \\
\hline $\begin{array}{l}\text { Sotelo et al. }{ }^{53} \\
\text { 2009, México }\end{array}$ & $\begin{array}{l}\text { Description } \\
\text { of early use in } \\
\text { patients with } \\
\text { ALF secondary to } \\
\text { hepatitis A }\end{array}$ & $\begin{array}{l}\text { Treatment } \\
\text { with } N \text {-Acetyl } \\
\text { Cysteine for } \\
\text { patients with } \\
\text { ALF secondary } \\
\text { to hepatitis A }\end{array}$ & $\begin{array}{l}\text { Clinical symptoms } \\
\text { and biochemical tests. }\end{array}$ & $\begin{array}{l}12 \text { patients } \\
\text { with } A L F \text {, of } 72 \\
\text { patients with } \\
\text { hepatitis } A\end{array}$ & $\begin{array}{l}6 \text { males; } 6 \text { females - } 9 \text { patients received oral } \\
\text { treatment and } 3 \text { through nasogastric intuba- } \\
\text { tion. Average treatment for } 15 \text { days, with one } \\
\text { case needing more } 15 \text { days }\end{array}$ \\
\hline $\begin{array}{l}\text { Uribe et al. }{ }^{16} \\
2013 \text {, Chile }\end{array}$ & $\begin{array}{l}\text { Analysis of } \\
\text { epidemiology and } \\
\text { outcomes of LT } \\
\text { in ALF }\end{array}$ & $\begin{array}{l}\text { LT in patients } \\
\text { from the waiting } \\
\text { list for LT in the } \\
\text { country }\end{array}$ & $\begin{array}{l}\text { Hospital protocol of } \\
\text { immunosuppression } \\
\text { regimen }\end{array}$ & 189 patients & $\begin{array}{l}230 \text { LT performed; ALF etiology was unknown } \\
\text { in } 50 \% \text { of cases; } 68 \% \text { of the patients had } 10- \\
\text { year survival, with } 90 \% \text { in the last } 3 \text { years }\end{array}$ \\
\hline $\begin{array}{l}\text { Silverio et al. }{ }^{13} \\
\text { 2015, Cuba }\end{array}$ & $\begin{array}{l}\text { Describe the out- } \\
\text { come of children } \\
\text { with ALF in Cuba }\end{array}$ & None & $\begin{array}{l}\text { Evaluated biochem- } \\
\text { ical and serological } \\
\text { tests of all patients }\end{array}$ & 31 patients & $\begin{array}{l}61 \% \text { of the cases were infectious, } 41 \% \text { by cyto- } \\
\text { megalovirus; spontaneous recovery in } 48 \% \text { of } \\
\text { cases (15); only } 3 \text { received LT and } 13 \text { died }\end{array}$ \\
\hline $\begin{array}{l}\text { Tannuri et al. }{ }^{77} \\
\text { 2016, Brasil }\end{array}$ & $\begin{array}{l}\text { Results of LT } \\
\text { before and after } \\
\text { living donor LT } \\
\text { became possible, } \\
\text { starting in } 2007\end{array}$ & $\begin{array}{l}\text { Living and dead } \\
\text { donor LT in ALF } \\
\text { patients }\end{array}$ & $\begin{array}{l}\text { Clinical symptoms } \\
\text { and biochemical tests. }\end{array}$ & 115 patients & $\begin{array}{l}48 \text { of the } 115 \text { patients with LT indication before } \\
\text { the institution started performing living donor } \\
\text { transplantation, } 67 \text { after; } 48 \% \text { mortality after } \\
\text { LT, with greater incidence in patients who } \\
\text { received LT from a dead donor, } 64.3 \% \text { before } \\
2007 \text { and } 50 \% \text { after; } 45 \% \text { with undefined } \\
\text { etiology }\end{array}$ \\
\hline
\end{tabular}


326 deaths reported (25.8\% of cases) and 634 transplant patients (50.1\% of cases).

The main studies, with their objectives, number of patients, and results are listed in Table 2.

\section{DISCUSSION}

This is the first review of the epidemiological aspects of FAH in the Latin America and Caribbean regions. With the results obtained, we evaluated the importance of $\mathrm{VH}$ in the causes of ALF. Although some of them are preventable by vaccination, VHs are the main infectious agents that cause FAH in the regions assessed, representing $94.3 \%$ of all cases described in this study, followed by yellow fever (2.3\%), and cytomegalovirus (1.5\%).

FAH secondary to VH has as its predominant cause the type A virus (HAV), representing $76.9 \%$ of all infectious causes; Argentina alone is responsible for $61.0 \%$ of all HAV cases. This reality seems to be changing after the introduction of HAV vaccination on a large scale in the country in $2005 .{ }^{78}$ Since 2006 , there was a $88.1 \%$ decrease compared to the period prior to the vaccination. Also were also no cases of FAH not notified in the country, nor the need for liver transplantation due to HAV since March 2007. ${ }^{79}$

It should be noted that, way behind HAV infection, there are also infections by the type $E$ virus (6.7\%), and type B (5.3\%), which could indicate the effectiveness of the Type B VH vaccination, which used to be more prevalent and nowadays is a rare cause of FAH. ${ }^{80}$

The country with the highest number of cases described was Argentina, with 53.6\% of all infectious HAF, followed by Brasil (25.4\%), and Chile (12.8\%). These data lead to the question: Do these numbers reflect the reality in these regions studied or just the publication capacity of researchers from each country? Regardless, these data provide important information on the causes of FAH in Latin American and Caribbean countries with potentially preventable diseases, thus providing the possibility of planning effective measures that can contribute to the reduction of morbidity and mortality. ${ }^{81}$

Among the drug or poisoning causes, we found a different reality from the one reported in other countries such as the United States and the United Kingdom, where paracetamol is the main agent of drug-induced FAH and mushrooms can cause enough poisoning to produce FAH. ${ }^{4.82}$ In Latin Amer- ica and the Caribbean, paracetamol appeared in only two out of a total of 43 cases. Surprisingly, fireworks were the main etiology of FAH in patients suffering from exposure to its chemical agents, especially yellow phosphorus. ${ }^{54}$

Considering the other causes, a considerable number of FAH cases due to autoimmune diseases appears in this review. There were 62 cases $(4.9 \%$ of the total), and Brasil (28 cases) and Argentina (16 cases) were responsible for the majority of the cases reported. There is also a large number of cases classified as idiopathic. There was a total of 340 cases classified this way (26.9\% of the total), in addition to 145 cases with no cause described, which proves the difficulty of performing more complex etiological diagnosis in the pediatric age range, only notifying the most common infectious causes. ${ }^{8.83}$

Another important data found in this study concerns the outcome of FAH cases submitted to liver transplantation (LT). Only half of the patients (50.1\%) was submitted to LT, which might reflect the low mortality rate found ( $25.8 \%$ of cases). ${ }^{7}$

Considering the population of the regions studied (Latin America and the Caribbean), we found a number of articles below expected, comprised mostly of case reports or case series and regional studies in a single center. We noticed the absence of multicenter studies of greater impact, which could best contribute to the review.

\section{CONCLUSION}

The avoidable causes of Fulminant Acute Hepatitis in Latin America and the Caribbean include the hepatitis viruses - especially hepatitis $\mathrm{A}$ - and poisonings. The active vaccination, basic sanitation, and public awareness can reduce the number of FAH patients and, consequently, the costs with the LT due to these causes. Paracetamol does not represent an emerging cause of FAH in this region, according to this review. Moreover, the high number of patients with idiopathic HAF or with no cause described draws attention and should guide public health efforts for the better elucidation of the epidemiology of FAH.

\section{Acknowledgments}

We thank Paola Pitta, who collaborated in the database search stages, and Simone Isidoro Prado, who collaborated with the elaboration of Figure 1. 


\section{RESUMO}

OBJETIVO: O objetivo desta revisão foi investigar a epidemiologia da hepatite aguda fulminante na América Latina e Caribe e identificar possiveis ações objetivando melhor compreensão e melhora do suporte desses pacientes.

MÉTODOS: Pesquisou-se o tema hepatite aguda fulminante em pediatria, publicado por autores da América Latina e Caribe nas bases de dados PubMed e SciELO por três diferentes investigadores no período de 2000 a 2016.

RESULTADOS: Foram encontrados 2.879 artigos nos bancos de dados pesquisados. Após seleção e exclusão de artigos de acordo com o protocolo de pesquisa, resultaram 68 estudos remanescentes para análise. Foram avaliados 1.265 casos com hepatite aguda fulminante, havendo predominância no sexo feminino (42,9\%), seguido do masculino (39,4\%), sendo que não houve a descrição de sexo em $17,7 \%$ dos casos. A principal causa foram as hepatites virais (HV), representando 45,1\% dos casos. O vírus da hepatite A foi responsável por $34,7 \%$ do total de casos e por $76,9 \%$ das causas infecciosas. Do total de pacientes, 26,9\% foram descritos como idiopáticos e $11,5 \%$ não tiveram causa descrita.

CONCLUSÃO: As causas evitáveis de hepatite aguda fulminante incluem os vírus da hepatite - principalmente o vírus da hepatite $A-e$ intoxicações. A vacinação ativa, o saneamento básico e a conscientização pública podem reduzir o número de doentes e, consequentemente, os custos com transplante hepático por essas causas.

PALAVRAS-CHAVE: Hepatite. Vacinas contra hepatite viral. Transplante de fígado. Revisão.

\section{REFERENCES}

1. Grek A, Arasi L. Acute liver failure. AACN Adv Crit Care. 2016;27(4):420-9.

2. Polson J, Lee WM; American Association for the Study of Liver Disease. AASLD position paper: the management of acute liver failure. Hepatology. 2005;41(5):1179-97.

3. O'Grady JG, Schalm SW, Williams R. Acute liver failure: redefining the syndromes. Lancet. 1993;342(8866):273-5.

4. Squires RH |r, Shneider BL, Bucuvalas |, Alonso E, Sokol R|, Narkewicz $M R$, et al. Acute liver failure in children: the first 348 patients in the pediatric acute liver failure study group. J Pediatr. 2006;148(5):652-8.

5. Devictor $D$, Tissieres $P$, Afanetti $M$, Debray $D$. Acute liver failure in children. Clin Res Hepatol Gastroenterol. 2011;35(6-7):430-7.

6. Bernal $W$, Auzinger $G$, Dhawan $A$, Wendon J. Acute liver failure. Lancet. 2010;376(9736):190-201.

7. Miloh T, Kerkar N, Parkar S, Emre S, Annunziato R, Mendez C, et al. Improved outcomes in pediatric liver transplantation for acute liver failure. Pediatr Transplant. 2010;14(7):863-9.

8. Lee WM, Squires RH Jr, Nyberg SL, Doo E, Hoofnagle JH. Acute liver failure: Summary of a workshop. Hepatology. 2008;47(4):1401-15.

9. United Nations Development Programme. Human development report 2016: Human development for everyone. New York: United Nations Development Programme; 2016. [cited 2018 Aug 22]. Available from: http:// hdr.undp.org/sites/default/files/2016_human_development_report.pdf

10. Moreira-Silva SF, Frauches DO, Almeida AL, Mendonça HF, Pereira FE. Acute liver failure in children: observations in Vitória, Espírito Santo State, Brasil. Rev Soc Bras Med Trop. 2002;35(5):483-6.

11. Cuarterolo M, López S, Dávila MG, Mondiglio C, Roy A, Zelazko M, et al. Autoimmune hepatitis in children. Initial presentation as fulminant hepatic failure. Acta Gastroenterol Latinoam. 2000;30(4):245-7.

12. Pereira RM, Tresoldi AT, Hessel G. Isoniazid-induced hepatic failure. Report of a case. Arq Gastroenterol. 2000;37(1):72-5.

13. Silverio CE, Smithen-Romany CY, Hondal NI, Díaz HO, Castellanos MI, Sosa O. Acute liver failure in Cuban children. MEDICC Rev. 2015;17(1):4854

14. Suso A, Sola A, Osay L, Moreno A, Salvatore A, Carena J. Acute lymphatic leukemia presenting in fatal fulminant hepatitis. Medicina (B Aires). 2014;74(2):178-9

15. Paula VS, Silva AP, Michel D, Melgaço JG, Vieira YR, Santos DC, et al. Acute liver failure in an immunocompetent patient. J Clin Virol. 2014;60(1):1-3.

16. Uribe M, Alba A, González G, Hunter B, Heine C, Iñiguez R, et al. Pediatric liver transplant outcome using severe hypernatremic donors. Transplant Proc. 2013;45(10):3726-7.

17. Acuña C, Zuleta R, Dalmazzo R, Valverde C, Uribe M, Alba A, et al. Pediatric liver transplantation experience and outcome in Chile. Transplant Proc. 2013;45(10):3724-5.
18. Muñoz O, Villa P, Echeverri C, Santos O, Restrepo JC, Marín JI, et al. Acute liver failure due to diffuse large B-cell lymphoma. Gastroenterol Hepatol. 2013;36(7):463-6.

19. Malla I, Fauda M, Casanueva E, Fernández MI, Amante M, Cheang Y, et al. Fulminant hepatic failure due to tuberculostatic drugs: case report. Arch Argent Pediatr. 2012;110(3):e35-8.

20. Sanchez MC, D'Agostino DE. Pediatric end-stage liver disease score in acute liver failure to assess poor prognosis. J Pediatr Gastroenterol Nutr. 2012;54(2):193-6.

21. Tannuri AC, Gibelli NE, Ricardi LR, Santos MM, Maksoud-Filho JG, Pinho-Apezzato ML, et al. Living related donor liver transplantation in children. Transplant Proc. 2011;43(1):161-4.

22. Santos DC, Martinho JM, Pacheco-Moreira LF, Araújo CC, Oliveira BC, Lago BV, et al. Fulminant hepatitis failure in adults and children from a Public Hospital in Rio de Janeiro, Brasil. Braz J Infect Dis. 2009;13(5):323-9.

23. Figueiredo CA, Cordovani NT, Castrignano SB, Alves VA, Kanamura CT, Oliveira MI, et al. Acute liver failure associated with rubella virus in a child. Pediatr Infect Dis J. 2010;29(6):573-4.

24. Uribe M, Alba A, Hunter B, Valverde C, Godoy J, Ferrario M, et al. Chilean experience in liver transplantation for acute liver failure in children. Transplant Proc. 2010;42(1):293-5.

25. Sasbón JS, Buamscha D, Gianivelli S, Imventarza O, Devictor D, Moreiro $\mathrm{R}$, et al. Clinical implications of hepatitis A virus ribonucleic acid detection and genotyping in acute liver failure in children in Argentina. Pediatr Crit Care Med. 2010;11(3):385-9.

26. Castillo L, Pérez C, Ruiz C, Bugedo G, Hernández G, Martínez |, et al. Intravascular hypothermia for the management of intracranial hypertension in acute liver failure: case report. Rev Med Chil. 2009;137(6):801-6.

27. Oliveira AL, Brustoloni YM, Fernandes TD, Dorval ME, Cunha RV, Bóia $M N$. Severe adverse reactions to meglumine antimoniate in the treatment of visceral leishmaniasis: a report of 13 cases in the southwestern region of Brasil. Trop Doct. 2009;39(3):180-2.

28. Cariús LP, Pacheco-Moreira LF, Balbi E, Leal CR, Gonzalez AC, Agoglia $L V$, et al. Living donor liver transplantation for acute liver failure: a single center experience. Transplant Proc. 2009;41(3):895-7.

29. Paiva WS, Andrade AF, Amorim RL, Figueiredo EG, Matushita H, Teixeira MJ. Intracranial pressure monitoring in children with fulminant hepatic failure. Rev Neurol. 2009;48(3):134-6

30. Uribe M, González G, Alba A, Godoy J, Ferrario M, Hunter B, et al. Living donor liver transplantation in pediatric patients with acute liver failure: safe and effective alternative. Transplant Proc. 2008;40(9):3253-5.

31. Ferreira $C T$, Vieira $S M$, Kieling $C O$, Silveira TR. Hepatitis $A$ acute liver failure: follow-up of paediatric patients in southern Brasil. J Viral Hepat. 2008;15(Suppl 2):66-8.

32. Munné MS, Vladimirsky S, Moreiro R, Ciocca M, Cuarterolo M, Otegui L, 
et al. Molecular characterization of hepatitis A virus in children with fulminant hepatic failure in Argentina. Liver Int. 2008;28(1):47-53.

33. Ciocca M, Ramonet M, Cuarterolo M, López S, Cernadas C, Alvarez F. Prognostic factors in paediatric acute liver failure. Arch Dis Child. 2008;93(1):48-51.

34. Ciocca M, Moreira-Silva SF, Alegría S, Galoppo MC, Ruttiman R, Porta G et al. Hepatitis $A$ as an etiologic agent of acute liver failure in Latin America. Pediatr Infect Dis J. 2007;26(8):711-5.

35. Dias LB Jr, Alves VA, Kanamura C, Oikawa RT, Wakamatsu A. Fulminant hepatic failure in northern Brasil: morphological, immunohistochemical and pathogenic aspects of Lábrea hepatitis and yellow fever. Trans R Soc Trop Med Hyg. 2007;101(8):831-9.

36. Munné MS, Vladimirsky S, Otegui L, Brajterman L, Castro R, Soto $S$ et al. Molecular characterization of hepatitis $E$ virus in three acute liver failure cases in children in Argentina. Acta Gastroenterol Latinoam. 2006;36(3):125-30

37. Munné MS, Cañero Velasco MC, Moreiro R, Vladimirsky S, Otegui L, Castro $R$, et al. Duration of viremia and fecal shedding of the virus in hepatitis A infected children. Acta Gastroenterol Latinoam. 2006;36(4):182-9.

38. Uribe M, Buckel E, Ferrario M, Godoy J, González G, Ceresa S, et al. Living related liver transplantation. Why this option has been discarded in a pediatric liver transplant program in Chile. Transplant Proc. 2005;37(8):3378-9.

39. Uribe M, Buckel E, Ferrario M, Godoy J, González G, Hunter B, et al. Pediatric liver transplantation: ten years of experience in a multicentric program in Chile. Transplant Proc. 2005;37(8):3375-7.

40. Cuarterolo M, Ciocca M, López S, Cervio G, Rojas L, Bianco G, et al. Evolution of children one year post liver transplant. Medicina (B Aires) 2005;65(5):402-8

41. Reto Valiente LV, Castillo Vergara J, Pichilingue Reto P, Pichilingue Prieto OA. Hepatotoxicity caused by antituberculosis drugs in pediatrics. Rev Gastroenterol Peru. 2005;25(4):362-5.

42. Cocozzella D, Méndez C, Malacalza |, Adrover R, Borzi S, Saba S, et al. Liver dysfunction in recipients of hematopoietic stem cells. Impact on mortality. Medicina (B Aires). 2005;65(2):113-6.

43. Uribe M, Buckel E, Ferrario M, Segovia R, González G, Hunter B, et al. $\mathrm{ABO}$-incompatible liver transplantation: a new therapeutic option for patients with acute liver failure in Chile. Transplant Proc. 2005;37(3):1567-8.

44. Diniz-Santos DR, Melo MC, Melo RF, Silva LR. Acute liver failure complicating viral hepatitis A. Braz J Infect Dis. 2004;8(2):180-3.

45. Fonseca |C, Souza RA, Brasil LM, Araújo |R, Ferreira LC. Fulminant hepatic failure in children and adolescents in Northern Brasil. Rev Soc Bras Med Trop. 2004;37(1):67-9.

46. Uribe M, Buckel E, Ferrario M, Godoy J, Blanco A, Hunter B, et al. Epidemiology and results of liver transplantation for acute liver failure in Chile. Transplant Proc. 2003;35(7):2511-2.

47. Buckel E, Uribe M, Brahm J, Silva G, Ferrario M, Godoy J, et al. Outcomes of orthotopic liver transplantation in Chile. Transplant Proc. 2003;35(7):2509-10

48. Fercovic A, Serra I, Serra L. Acetaminophen hepatotoxicity in an alcoho addicted student. Case report. Rev Med Chil. 1999;127(2):202-5.

49. Galizzi-Filho I, Andrade MO, Cota MM, Penna Fl, Figueiredo-Filho PP, Valadares CA, et al. Wilson's disease ("hepatic form") in a region endemic for schistosomiasis mansoni: clinical presentation of 25 patients. Arq Gastroenterol. 1998;35(1):11-7.

50. Figueiredo CA, Oliveira MI, Tarandachi PR, Carvalho WB, Kanamura CT, Scatena RS, et al. Fatal acute liver failure in a child due to acquired rubella infection. J Clin Virol. 2014;61(1):1-2.

51. Bucaretchi F, Fernandes CB, Branco MM, Capitani EM, Hyslop S, Caldas $\mathrm{IP}$, et al. Acute liver failure in a term neonate after repeated paracetamo administration. Rev Paul Pediatr. 2014;32(1):144-8.

52. Gutierrez-Reyes $G$, del Carmen Garcia de Leon M, Varela-Fascinetto G Valencia P, Pérez Tamayo R, Rosado CG, et al. Cellular senescence in livers from children with end stage liver disease. PLoS One. 2010;5(4):e10231.

53. Sotelo N, Angeles Durazo M, Gonzalez A, Dhanakotti N. Early treatment with $\mathrm{N}$-acetylcysteine in children with acute liver failure secondary to hepatitis A. Ann Hepatol. 2009;8(4):353-8.

54. Santos O, Restrepo IC, Velásquez L, Castaño |, Correa G, Sepúlveda E, et al. Acute liver failure due to white phosphorus ingestion. Ann Hepatol. 2009;8(2):162-5
55. Jiménez G, Cambronero V, Morales C, Mora A, Guzmán C, liménez-Rivera C. Wilson's disease: pediatric experience in Costa Rica. Gastroenterol Hepatol. 2009;32(4):274-8.

56. Gentile A. The need for an evidence-based decision-making process with regard to control of hepatitis A. J Viral Hepat. 2008;15(Suppl 2):16-21.

57. Ospitaleche M, Lagomarsino G, Pinchak C. Actualización de hepatitis autoinmune en pediatría: reporte de un caso clínico y revisión de la literatura. Arch Pediatr. 2016;87(2):115-24

58. Bravo-Jaimes KM. Hemophagocytic lymphohistiocytosis presenting as acute liver failure in a patient with Hodgkin lymphoma: case report and review of the literature. Rev Gastroenterol Peru. 2015;35(3):256-7.

59. Mainardi V, Ardao G, Mirazo S, D'Albora, Valverde M, Gaibizzo R, et al. Primer caso de falla hepática aguda por virus de la hepatitis E en Uruguay. Arch Med Interna. 2014;36(3):111-4

60. Viviani G, Paula AP, Roque EC. Falla hepática fulminante por virus Epstein Barr: rol de los corticoides. Caso clínico. Rev Chil Pediatr. 2013;84(3):313-7.

61. Roque JE, Ríos GM, Pinochet CV, Vignolo PA, Humeres RA, Ríos HR, et al. Falla hepática fulminante en niños. Rev Chil Pediatr. 2009;80(2):144-9.

62. Viana CF, Rocha TD, Cavalcante FP, Valença JT Jr, Coelho GR, Garcia JH. Liver transplantation for acute liver failure: a 5 years experience. Arq Gastroenterol. 2008;45(3):192-4

63. Roque JE, Ríos GM, Hepp JK, Humeres RA, Innocenti FC, Ríos HR, et al. Falla hepática fulminante por parvovirus B 19 y trasplante hepático, caso clínico. Rev Chil Pediatr. 2005;76(4):393-6.

64. Vidal CA, Gonzalez LF, Ariza, F. Falla hepática fulminante aguda: cuando el transplante hepático es la única solución. Rev Colomb Anestesiol. 2005;33(1):65.

65. Santos O, Londoño M, Marín J, Muñoz O, Mena Á, Guzmán C, et al. An experience of liver transplantation in Latin America: a medical center in Colombia. Colomb Med (Cali). 2015;46(1):8-13.

66. Yarur A, Castro L, Segovia R, Roblero IP, Uribe M, Ferrario M, et al. Smallfor-size syndrome. Report of one case. Rev Med Chil. 2009;137(7):918-22.

67. Restrepo |C, Muñoz J-F, Correa G, Zuleta |, Londoño M, Botero A, et al. Hepatotoxicidad detectada en un hospital de cuarto nivel en la ciudad de Medellín. Acta Med Colomb. 2008;33(4):261-7.

69. Bucaretchi F, Vicente DC, Pereira RM, Tresoldi AT. Dapsone hypersensitivity syndrome in an adolescent during treatment during of leprosy. Rev Inst Med Trop Sao Paulo. 2004;46(6):331-4.

69. Ridaura-Sanz C, Gutierrez-Castrejón P. Young infant with febrile syndrome, acute progressive encephalopathy and hepatic functional alteration. Gac Med Mex. 2001;137(4):347-54.

70. Porta G, Gayotto LC, Alvarez F. Anti-liver-kidney microsome antibody-positive autoimmune hepatitis presenting as fulminant liver failure. J Pediatr Gastroenterol Nutr. 1990;11(1):138-40.

71. Cordero J, Baeza J, Zacarías J, Brinck P, Vega E, Maureira E, et al. Fulminant hepatic failure in children. Rev Med Chil. 1990;118(7):753-8.

72. Villamil A, Bisignano L, Orozco F, Bandi JC, Barcán L, McCormack L, et al. The Argentine experience with human immune deficiency virus positive patients in the waiting list for liver transplantation: preliminary analysis. Acta Gastroenterol Latinoam. 2013;43(2):113-20.

73. Santos DC, Neves PC, Azeredo EL, Pelajo-Machado M, Martinho JM, Pacheco-Moreira LF, et al. Activated lymphocytes and high liver expression of IFN- $\gamma$ are associated with fulminant hepatic failure in patients. Liver Int. 2012;32(1):147-57.

74. Coelho MP, Afonso RC, Hidalgo R, Felga G, Almeida MD, Della-Guardia $B$, et al. Results of retransplantation for primary nonfunction in a single center. Transplant Proc. 2011;43(1):174-6.

75. Pinho-Apezzato ML, Tannuri U, Tannuri AC, Mello ES, Lima F, Gibelli NE, et al. Multiple clinical presentations of lymphoproliferative disorders in pediatric liver transplant recipients: a single-center experience. Transplant Proc. 2010;42(5):1763-8.

76. Duarte-Rojo A, Zepeda-Gómez S, García-Leiva J, Remes-Troche JM, Angeles-Angeles A, Torre-Delgadillo A, et al. Liver transplantation for neurologic Wilson's disease: reflections on two cases within a Mexican cohort. Rev Gastroenterol Mex. 2009;74(3):218-23.

77. Tannuri AC, Porta G, Kazue Miura I, Santos MM, Moreira DA, Rezende NM, et al. Pediatric acute liver failure in Brasil: is living donor liver transplantation the best choice for treatment? Liver Transpl. 2016;22(7):100613. 
78. Vizzotti C, González |, Rearte A, Urueña A, Pérez Carrega M, Calli R, et al. Single-dose universal hepatitis A immunization in Argentina: low viral circulation and high persistence of protective antibodies up to 4 years. I Pediatric Infect Dis Soc. 2015;4(4):e62-7.

79. Vizzotti C, González J, Gentile A, Rearte A, Ramonet M, Cañero-Velasco $M C$, et al. Impact of the single-dose immunization strategy against hepatitis A in Argentina. Pediatr Infect Dis J. 2014;33(1):84-8.

80. Chen HL, Chang C), Kong MS, Huang FC, Lee HC, Lin CC, et al. Pediatric fulminant hepatic failure in endemic areas of hepatitis $B$ infection: 15 years after universal hepatitis B vaccination. Hepatology. 2004;39(1):58-63.

81. Cervio G, Trentadue J, D'Agostino D, Luque C, Giorgi M, Armoni J, et al. Decline in HAV-associated fulminant hepatic failure and liver transplant in children in Argentina after the introduction of a universal hepatitis A vaccination program. Hepat Med. 2011;3:99-106.

82. Lee WM. Acetaminophen and the U.S. Acute Liver Failure Study Group: lowering the risks of hepatic failure. Hepatology. 2004;40(1):6-9.

83. Squires RH |r. Acute liver failure in children. Semin Liver Dis, 2008;28(2):153-66. 